\title{
2006-1278: USING REFLECTIVE ESSAYS AS PART OF A MIXED METHOD APPROACH FOR EVALUATING A FRESHMAN LIVING-LEARNING COMMUNITY FOR ENGINEERING AND SCIENCE STUDENTS
}

\section{Jennifer Light, University of Washington}

Jennifer Light is a $2005 \mathrm{Ph}$.D. graduate in Engineering Education from Washington State University and was recently awarded a National Academy of Engineering post doctoral appointment with the University of Washington Center for Engineering Education. She is the author of several publications on engineering learning communities and assessment.

\section{Laura Girardeau, Washington State University}

Laura Girardeau, M.S., is a Learning Designer at Washington State University's Center for Teaching, Learning, and Technology, and was formally a Jr. Researcher in the Laboratory for Interactive Learning Technologies at the University of Hawaii. She is co-author of several publications on collaborative learning.

\section{Jennifer Beller, Washington State University} Jennifer M. Beller, Ph.D. is an Associate Professor of Educational Psychology in the Department of Educational Leadership and Counseling Psychology at Washington State University. She is co-author of six ASEE proceeding papers, including one that won the ASEE Best Conference Paper.

\section{Greg Crouch, Washington State University}

Greg Crouch is associate professor of chemistry at Washington State University. In addition to organic chemistry research, Greg's educational research focuses small group cooperative learning and technology-enhanced education. Greg has designed, implemented, and assessed a prototype "flexible classroom" where lecture space, small group collaboration space, and technology access are combined; has implemented and evaluated a problem-based undergraduate learning community focusing on science and mathematics majors and been funded by the NSF to develop adaptive, web-based science and math teaching modules to augment traditional lecture courses. 


\title{
Using Reflective Essays as Part of a Mixed-Method Approach for Evaluating a Freshman Living-Learning Community For Engineering and Science Majors
}

\begin{abstract}
Researchers at a large Northwest research university developed a living-learning community (LLC) program in 2004 to increase retention of freshmen engineering and science students, improve academic abilities, and increase college engagement. A mixed-method approach for program evaluation was employed providing a more holistic evaluation of the program's effectiveness. The evaluation included qualitative measures for grades, retention, and surveys, along with quantitative measures from focus groups, observations and content analysis of reflective essays. Of these qualitative components, the reflective essay content analysis was particularly insightful. Reflective essays are not often used for assessing and evaluating programs, however, their use in this study provided a unique opportunity for understanding the college experience from the students' perspective and for explaining quantitative results from grades, retention, and engagement surveys. Essay analysis revealed differences between engineering and science students, indications of their intellectual development, and how they were transitioning to college life. This paper presents a methodology for content analysis of reflective essays, describes how the results were used to triangulate and explain other the other measures, and identifies areas for improvement in the LLC program.
\end{abstract}

\section{Introduction}

Traditional evaluation of LLC programs encompassing various facets of a student's life during the first year of college are often limited to statistical analyses of grades, retention, and responses to surveys, indicating what happened but not why it happened. These measures fail to address the cumulative effects of social and academic experiences. They also ignore the temporal changes that freshmen go through during their first year and how such programs affect these changes.

The semester-long LLC described in this paper began as an attempt to improve the engagement, academic abilities, and retention (to the following year as well as retention in the major) of engineering and science students. Researchers at a large northwestern research university developed a novel LLC for entering freshmen encompassing both residential and academic life. The program, called "Teniwe" (meaning "to talk" in the Native American language of the Nez Perce), was a voluntary, self-selected program that housed students with a common major (engineering and biotech) and pre-registered them in a common block of classes during the Fall 2004 semester. A corresponding seminar class facilitated community building, familiarization with university resources, and academic improvement by teaching study skills and providing content help for linked classes.

As with any other academic program, program evaluation is an essential component for program success and continuation. Commonly used evaluation measures: retention, grades, and 
engagement where used, however, the impacts of this LLC were more complex than these quantitative tests could measure. Combining both quantitative and qualitative measures provided opportunities for not only triangulating the results but also providing supporting evidence and possible explanations for the retention, grades, and engagement results. The qualitative data collected also provides additional insight into whether the program was received by the students as it was intended.

\section{Limitations}

Students in the Teniwe LLC self-selected into the program. Students that listed engineering as their first or second choice for major were sent a letter soliciting their participation in the program and were accepted on a first-come-first-served basis. Since the program was developed and geared for students entering this specific university, it is foremost a case study and assessment rather than a research study. Erwin ${ }^{1}$ outlined two important contrasts: 1) "Assessment guides good practice, whereas research guides theory and tests concepts" and 2) "Assessment typically has implications for a single institution, whereas research typically has broader implications for higher education." These contrasts hold true for this study, in which administrators and researchers were faced with resource and time limitations, organizational contexts, and design limitations.

\section{Literature Review}

A variety of methods for evaluating learning communities have been proposed by Moore ${ }^{2}$ Tinto, Love, \& Russo, ${ }^{3}$ and Wilkie. ${ }^{4}$

Moore used Perry's ${ }^{5}$ theory of intellectual development as a basis for measuring the effects of learning communities. A survey instrument, the Measure of Intellectual Development (MID) which is a survey instrument and an essay-writing test derived from Perry's work, was used to determine impacts from the learning community. The MID was given to learning community participants and also to peers who were scored on a 1 to 5 point scale. LLC participants showed more developmental gains than their non-participating counterparts.

Love, Tinto, \& Russo ${ }^{3}$ approached evaluation by first assuming that learning communities were effective ways to respond to the academic and social needs of students. They were "casting [their] nets widely in an effort to be open to unexpected phenomena." They hoped that this would eliminate subjective value judgments and help them develop an understanding of how each program met the needs of students at each institution and how it shaped student learning and persistence.

Wilke ${ }^{4}$ proposed a more "institutional" method by responding to a series of questions divided into three categories: student performance, student development, and retention. Measures were mixed, using both quantitative methods (grades, retention, course completion, credits completed) and qualitative methods (students' responses to questions about learning communities, their perceptions of themselves as learners, and difficulties encountered in their learning communities). Wilke asserts the inclusion of quantitative data despite arguments against the appropriateness of such measures (grades might reflect actual learning, retention may 
be affected by non-academic factors) because there is value in building a case directed toward administrators using more straightforward measures of grades and retention for funding learning communities.

The evaluation method for this case study employs many of Wilke's same aspects to provide a more comprehensive authentic evaluation using quantitative and qualitative data and methods to assess the LLC and to understand the impacts of the different components of the program.

\section{Methodology}

Table 1 lists all the program outcomes along with related assessment measures. Although this paper discusses only the reflective essays - see Light ${ }^{6}$ for a more complete discussion of the other assessment measures - all assessment measures used for evaluation of this LLC are included here to enhance contextual understanding of the reflective essay results (reflective essay measure is highlighted in the table). Although some qualitative data overlap in two or more categories, the predominant category is listed (e.g., focus groups are listed under engagement, but results elucidate retention and grade issues as well as engagement). Results from these assessment measures are found in Table 2 of the "results" section of this paper.

Table 1. Program evaluation measures.

\begin{tabular}{|c|c|c|c|}
\hline Outcome & Measure & Instrument & Analysis \\
\hline \multirow[t]{4}{*}{ Engagement } & \multirow[t]{2}{*}{ Student surveys } & Course evaluation & $\begin{array}{l}\text { - Aggregate responses to learning } \\
\text { environment and critical } \\
\text { engagement sections to gauge } \\
\text { overall satisfaction with class } \\
\text { - Benchmark responses pertaining } \\
\text { to engagement questions } \\
\text { - Analyze open-ended responses to } \\
\text { questions for student suggestions } \\
\text { for class improvement (Freshmen } \\
\text { Seminar and chemistry class only) }\end{array}$ \\
\hline & & $\begin{array}{l}\text { NSSE }^{7} \text { survey } \\
\text { collected in } \\
\text { February } 2005\end{array}$ & $\begin{array}{l}\text { Compare NSSE results to } \\
\text { engineering students locally and } \\
\text { nationally using t-test, } \\
\text { frequencies, and effect size, } \\
\text { Cohen's } d^{8} \text { where } .2 \text { is small, } .5 \\
\text { medium, and } .8 \text { is large. }\end{array}$ \\
\hline & Interviews & Focus Groups & $\begin{array}{l}\text { Identify students' perceptions of } \\
\text { Teniwe program; program } \\
\text { strengths, weaknesses, } \\
\text { improvement }\end{array}$ \\
\hline & Student essays & Reflective essays & $\begin{array}{l}\text { Content analysis of reflective } \\
\text { essays for common themes } \\
\text { regarding engagement, program } \\
\text { evaluation, and students' } \\
\text { development level }\end{array}$ \\
\hline
\end{tabular}




\begin{tabular}{|c|c|c|c|}
\hline & Observation & $\begin{array}{l}\text { Observations } \\
\text { during common } \\
\text { classes }\end{array}$ & $\begin{array}{l}\text { Observations of social behavior of } \\
\text { Teniwe students compared to } \\
\text { peers }\end{array}$ \\
\hline \multirow[t]{3}{*}{$\begin{array}{l}\text { Academic } \\
\text { Achievement }\end{array}$} & $\begin{array}{l}\text { Grades in } \\
\text { common classes }\end{array}$ & \multirow{2}{*}{$\begin{array}{l}\text { Data collected } \\
\text { through } \\
\text { institutional } \\
\text { database }\end{array}$} & \multirow[t]{2}{*}{$\begin{array}{l}t \text {-tests, effect size } d^{9} \text { where } .2 \text { is } \\
\text { small, } .3 \text { medium, and } .8 \text { large. }\end{array}$} \\
\hline & $\begin{array}{l}\text { Student } \\
\text { Preparedness } \\
(\text { AIN) }\end{array}$ & & \\
\hline & $\begin{array}{l}\text { Study skills } \\
\text { assessment }\end{array}$ & $\mathrm{LASSI}^{10}$ & comparison to national norms \\
\hline \multirow[t]{2}{*}{ Retention } & $\begin{array}{l}\text { Retention in } \\
\text { college }\end{array}$ & \multirow{2}{*}{$\begin{array}{l}\text { Data collected } \\
\text { through } \\
\text { institutional } \\
\text { database }\end{array}$} & \multirow{2}{*}{$\begin{array}{l}\text { Pearson's } \chi^{2} \text {, effect size Cramer's } \\
\mathrm{V}^{9} \text { where. } 10 \text { is small, } .30 \\
\text { medium, and } .50 \text { large. }\end{array}$} \\
\hline & $\begin{array}{l}\text { Retention in } \\
\text { engineering or } \\
\text { science }\end{array}$ & & \\
\hline
\end{tabular}

\section{Study Participants}

Eighty-six students self-selected by signing up for the Teniwe program. Five dropped during the first week, leaving a total of 81 students. Fifty-nine were majoring in engineering and 22 declared a biotech major (biology, chemistry, mathematics, pre-veterinary, or zoology). Engineering majors included electrical, mechanical, civil, material science, biomedical, or computer science engineering. All students were first-time entering freshmen who completed high school in May, 2004 and were between the ages of 18 and 19.

The study used 202 engineering peer comparison students and 201 biotech comparison students with similar characteristics (i.e. graduated in May of 2004, lived in one of the residence halls, were freshmen starting college for the first time, listed one of the biotech majors of biology, chemistry, mathematics, pre-veterinary, or zoology or engineering as their major, and were 18-19 years old) for grade, engagement, and retention comparison. Gender, ethnicity, and incoming preparedness as measured by the Academic Index Number (AIN, a Washington state formula that combines high school GPA and SAT scores to predict preparedness for college) are detailed in Figures 1, 2, and 3, respectively. 


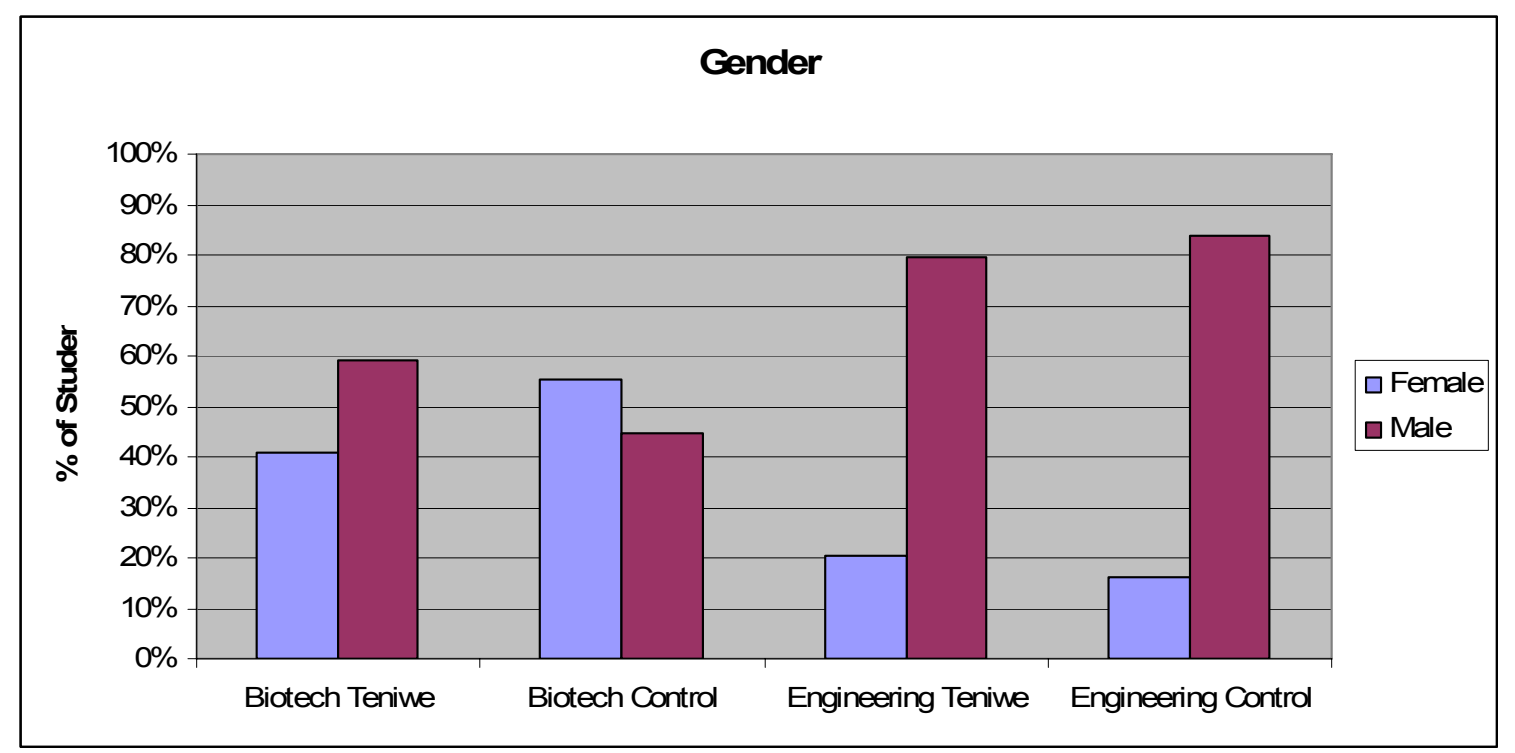

Figure 1. Gender.

The majority of students were Caucasian, followed by Asian, Native Hawaiian, or Pacific Islander, then Hispanic, Latino/a, or Spanish origin. Figure 2 outlines the number and ethnicity of the Teniwe and control students.

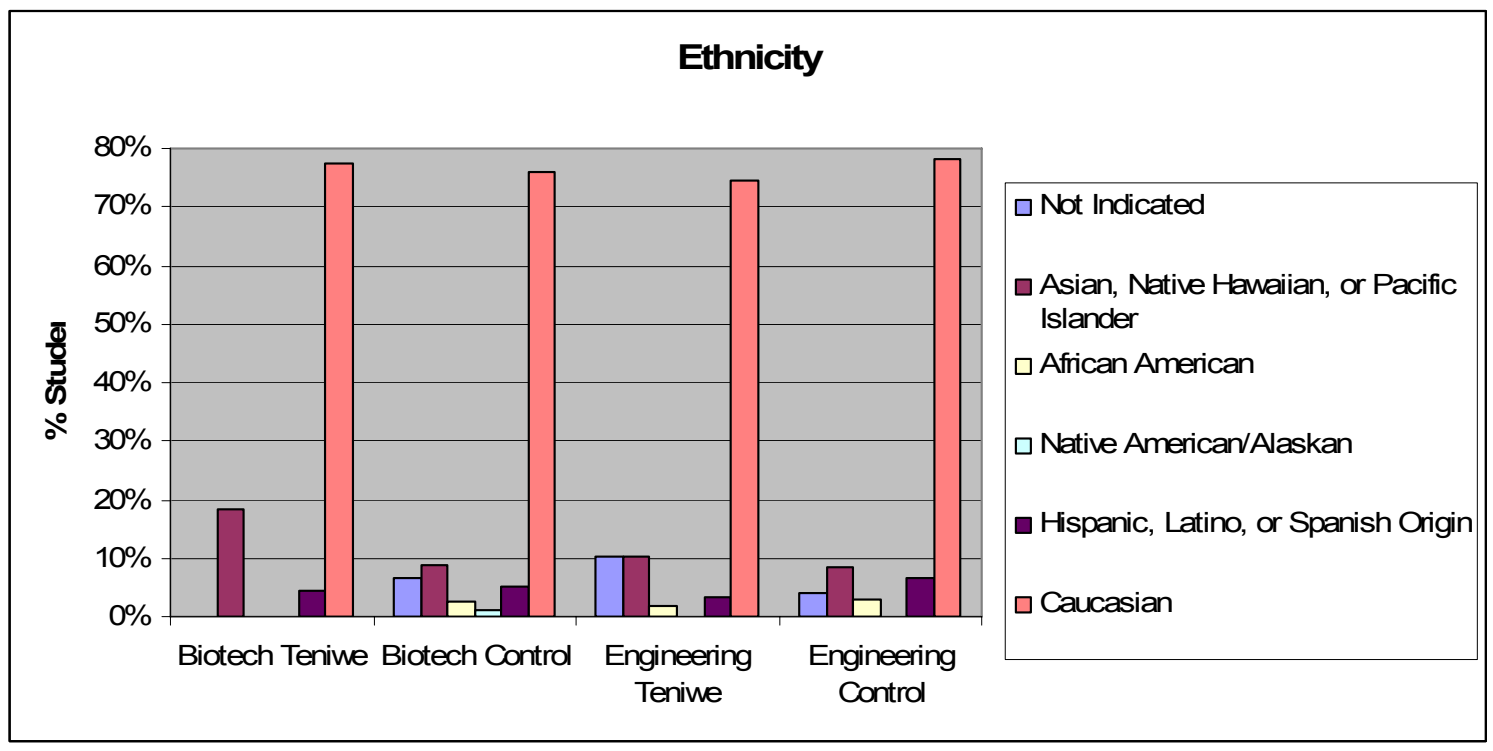

Figure 2. Ethnicity.

Boxplots of the AIN for Tenwie and control students are depicted in Figure 3. AIN can range from zero (student was home-schooled and does not have an AIN) to 100 (highest SAT score and highest high school GPA). Heavy black lines represent the average AIN, and the upper and lower parts of the box represent one standard deviation above and below. The whiskers represent the second standard deviation values. 


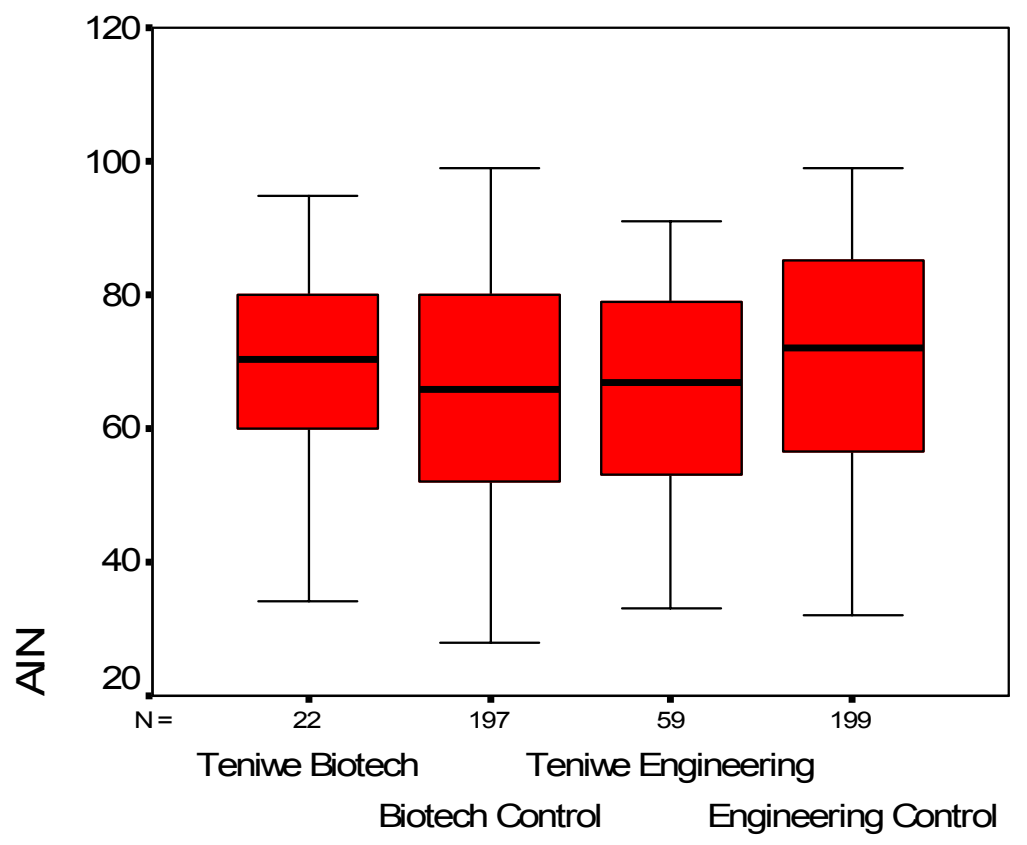

Figure 3. AIN boxplot.

\section{Content Analysis of mid- and end-term reflective essays}

Researchers were interested in how students perceived the Teniwe program, their college goals and expectations, study habits, engagement activities, and their developmental level according to the Perry ${ }^{5}$ scheme. Students in the six different Freshmen Seminars wrote two reflective essays on their goals, growth, and experiences, one essay during midterms and one at the end of the semester. Questions were available to the students to guide their essays, although they were not required to answer the questions directly.

Forty-five mid-term and 74 end-term essays were analyzed constituting a 90\% sampling rate (mid-term essays were unavailable for analysis for two of the groups). Essays were grouped by their freshmen seminar class; thus, there were two biotech seminar classes and four engineering seminar classes for a total of six different seminar classes.

Each reflective essay was read once for common themes and re-read for responses to common questions posed by the peer leader, as well as interesting insights. Essays were then read a third time for comments specific to the themes which developed. Themes centered on the students': (1) view of their academic abilities, strategies, and goals; (2) perceptions of differences between college and high school; (3) perceptions of the freshmen seminar and the Teniwe LLC program; and 5) development according to Perry. ${ }^{5}$

Essay coding was performed for holistic meaning rather than line by line. Themes were categorized by questions as listed above, defining properties of that category, and identifying the timing (mid- or end-term) of the comment. ${ }^{11}$ Results were expressed by coded segment rather than by student, since some students made duplicate comments. The most common comments 
for each coding category (goals, problems, benefits, and freshman seminar comments) were included in the results, as well as some outliers of interest.

Theoretical sensitivity ${ }^{11}$ was increased by the researcher's grounding and familiarization of research in learning communities, collaborative learning, and student development; the researcher's personal experience in developing the Teniwe program and working with freshmen by teaching and interacting in freshmen seminar and the introductory engineering class; and through analytic process having and continuing to work with previous year's living-learning program, data, focus group responses, seminar responses, and survey responses.

To verify validity of coding categories and counts, a second researcher coded common themes from all essays using their own code words that were descriptive of the content. This researcher has over five years' experience coding and analyzing undergraduate discourse including essays. To eliminate bias, the same second coder, who was not otherwise involved with the study, conducted final counts of matching and non-matching codes to determine interrater reliability and then summarized the results. Codes in agreement were required to occur in the same sentence, and the number of differences between coders was noted in contrast with the total coded segments. Coder agreement on all essays averaged $89 \%$, ranging from $81 \%$ to $95 \%$ for each freshman seminar group. Due to the qualitative nature of the data and the large scope of the case study, a Kappa reliability analysis was not run. Results summarized the most common student comments made related to various topics addressed in the essays.

\section{Results}

Results from all the different assessments and their relation to the Teniwe goals are summarized in Table 2 (reflective essay results are highlighted in the table).

Table 2. Measure or instrument and results.

\begin{tabular}{|l|l|l|}
\hline Outcome & $\begin{array}{l}\text { Instrument or } \\
\text { Measurement }\end{array}$ & Results \\
\hline Engagement & Course Evaluation & $\begin{array}{l}\text { - developed community with other students; } \\
\text { - mostly satisfied with math, biology, and chemistry; } \\
\text { - mostly dissatisfied with freshmen seminar and introductory } \\
\text { engineering; } \\
\text { - suggested improvements to freshmen seminar and chemistry as } \\
\text { described in course evaluation section below. }\end{array}$ \\
\cline { 2 - 4 } & NSSE survey & $\begin{array}{l}\text { - overall higher engagement reported by LLC students compared } \\
\text { to peers particularly in time spent working in groups, quality of } \\
\text { relationships, time usage, and positive institutional environment; } \\
\text { - LLC students were not as satisfied with their overall } \\
\text { educational experience or satisfaction with their college. }\end{array}$ \\
\cline { 2 - 4 } & Focus Groups & $\begin{array}{l}\text { - liked common living/classes; } \\
\text { - asked for class content help from each other; } \\
\text { - believed LLC Teniwe program was "worth it" overall but not } \\
\text { freshmen seminar class. }\end{array}$ \\
\hline
\end{tabular}




\begin{tabular}{|c|c|c|}
\hline & $\begin{array}{l}\text { Content analysis } \\
\text { from reflective } \\
\text { reports }\end{array}$ & $\begin{array}{l}\text { - worked with peers in study groups and projects; } \\
\text { - made friends; } \\
\text { - perceived Teniwe as helping them make the transition to } \\
\text { college primarily through friends and ready-made study groups; } \\
\text { - majority of students in dualistic phase as categorized by Perry } \\
\text { development scheme; } \\
\text { - believed they developed independence and social skills during } \\
\text { semester; } \\
\text { - identified problems with study habits but did not always } \\
\text { mitigate those problems; } \\
\text { - liked common living/classes; } \\
\text { - used campus resources - primarily the recreation center. }\end{array}$ \\
\hline & Observation & $\begin{array}{l}\text { - had to be "forced" into sitting together in freshmen seminar } \\
\text { class groups during first two weeks. After that students } \\
\text { routinely sat together in freshmen seminar and in other classes; } \\
\text { - no difference between Teniwe students and peers interacting } \\
\text { more or less with teacher. }\end{array}$ \\
\hline \multirow[t]{3}{*}{$\begin{array}{l}\text { Academic } \\
\text { Achievement }\end{array}$} & $\begin{array}{l}\text { Grades in common } \\
\text { classes }\end{array}$ & \multirow{2}{*}{$\begin{array}{l}\text { - LLC students had significantly higher average grades in } \\
\text { chemistry class; } \\
\text { - LLC students had higher grade averages in math, biology, and } \\
\text { engineering but not significantly. } \\
\text { - LLC students had lower AIN scores in all analyzed classes. }\end{array}$} \\
\hline & $\begin{array}{l}\text { AIN in common } \\
\text { classes }\end{array}$ & \\
\hline & $\begin{array}{l}\text { LASSI (study skills } \\
\text { assessment) }\end{array}$ & $\begin{array}{l}\text { - Teniwe students had weak study skills mostly in lower } 50^{\text {th }} \\
\text { percentile compared to national norms. }\end{array}$ \\
\hline Retention & $\begin{array}{l}\text { Retention in } \\
\text { college }\left(10^{\text {th }} \text { day }\right) \\
\text { Retention in major }\end{array}$ & $\begin{array}{l}\text { - no difference in semester retention; } \\
\text { - no difference in annual retention; } \\
\text { - significant difference for engineering control students who } \\
\text { "switched" out of engineering more than Teniwe engineering } \\
\text { students; } \\
\text { - no difference in "switching" majors for biotech students and } \\
\text { control peers. }\end{array}$ \\
\hline
\end{tabular}

\section{Content analysis on mid-and end-term reflective essays}

The reflective essays provided a rich source of qualitative data. Summaries for each of the groups are provided below. Further analysis categorized comments into several themes that emerged during the analysis: student development, identifying psychological processes and attitudes, differences among the Teniwe students themselves, and program evaluation from the students' perspective. The summaries for each seminar class and the analysis categorized by theme follow.

Understanding student expectations and their reactions in college can be contextualized if some idea of their development level and psychological processes and attitudes is known. Using Perry's ${ }^{5}$ stages of student intellectual development, we can make sense of student course evaluations, focus group comments, their behavior, and to some extent their grades. Bean ${ }^{12}$ identified psychological processes (self-efficacy, approach/avoidance behavior, and locus of control) that facilitate a student's decision to stay in college or leave, many of which are 
reflected in these essays. Additionally, some differences were noted between the LLC Teniwe students themselves and appeared to be aligned by their major. Finally, the essays were mined for information regarding the students' perceptions of the LLC program and in essence provided a "student evaluation" for the program.

$\underline{\text { Seminar group } 1 \text { summary }}$

Common student goals for the year included making friends and getting good grades. Many students felt they had benefited from common living arrangements and campus resources provided by the LLC. Other common benefits of the program included meeting people, forming study groups, gaining study skills, and building community. The biggest problem students faced was time management. No mid-term reflective essays were available for analysis for this group so only final essays were analyzed.

\section{$\underline{\text { Seminar group } 2 \text { summary }}$}

The most common student goals included getting good grades and making friends. The biggest problems facing students by far were procrastination and time management. The most common benefits that the students noted were improvement in time management and study skills, as well as a newfound sense of community.

Although a few students felt that the freshman seminar helped them, for instance in gaining communication skills, many students did not end up liking the course by the end of the semester. Some felt that the course was a review of skills already learned in high school, and several were disappointed that it wasn't a study hall. It may be necessary for administrators to clarify that freshman seminar is not simply a study hall and will require course work.

It is interesting to note that many students felt that good grades correlate directly with effort, although two found that this attitude didn't always work.

\section{$\underline{\text { Seminar group } 3 \text { summary }}$}

The most common goal noted was getting good grades, followed by improving study skills and making friends. The most common comments on program benefits included making friends and accessing campus resources. Other benefits included improving study skills, having common living arrangements and common classes, and stopping procrastination. This improvement in procrastination is important since procrastination was by far the most common problem that students admitted to having. Other common problems included lack of preparation for college in high school and lack of motivation for "boring" subjects.

Many students commented that freshman seminar was not useful to them academically because it was a review, and some felt patronized by this. However, many students benefited from the support given by the peer facilitators, and some enjoyed the research project. One student noted that she felt constricted by the strong social ties of the LLC Teniwe program, wanting to meet more people outside of the program. No mid-term reflective essays were available for this seminar group, consequently only final essays were analyzed. 
$\underline{\text { Seminar group } 4 \text { summary }}$

The most common goal noted for the year by students was to get good grades, followed by making friends. Nearly half of the students felt that good grades were a direct result of effort. However, several changed their minds about this by the end of the term when they found that either they got good grades without much effort or tried hard and did not receive good grades.

As with most of the other groups, procrastination was the most common problem noted by students, followed by a lack of preparation in high school for college work, and time management issues. Major benefits of the LLC program included common living and learning communities, gaining study skills, making friends, and improving time management skills.

As for the freshman seminar class itself, students' most common comment was that they enjoyed getting to know their schoolmates and peer facilitators. Many students felt that the freshman seminar was a review of skills they already had and required a lot of busy work that wasn't useful. Many students felt that the freshman seminar required too much time for too few credits, and they had been told in the initial advising program that freshman seminar would be a study hall. These students were quite disappointed because of this expectation.

Interestingly, several students noted that they are not motivated to change their habits regarding procrastination because they feel that they work well under pressure. Two students had the perception that the LLC program was geared to serious students only.

\section{$\underline{\text { Seminar group } 5 \text { summary }}$}

The most common goals students had at the midterm point were obtaining good grades, improving study skills, and improving time management. They felt that their biggest obstacles to these goals were procrastination and unrealistic expectations of the college experience. Even at the midterm point, the biggest benefit of the LLC program that students mentioned were that it helped them improve their study skills, make friends, and learn to manage their time.

By the time of the final essay, the most common goals that students felt they had reached were that they had made friends, gotten help from friends, formed study groups and improved their time management skills. A few students mentioned that although freshman seminar helped them with social skills and networking, they did not feel that it helped them academically.

\section{$\underline{\text { Seminar group } 6 \text { summary }}$}

The most common student goals were to make friends, improve study skills, and improve grades. Students' most common struggle was with procrastination. Several students mentioned that their study skills had already improved by the midterm point, that they felt more part of a community, and that they had formed study groups. By the time of the final essay, many students felt that they made friends and built community, as well as learning to manage their time and improve study skills. A few mentioned that the program helped them set goals and reflect on their progress, which motivated them. 
$\underline{\text { Student intellectual development }}$

Analysis of the reflective essays using Perry's ${ }^{5}$ scheme of student intellectual development indicated LLC students appeared to be predominately in the "dualist" stage where knowledge is truth - factual information, correct theories, and right answers $\left(\right.$ Perry $\left.^{5}\right)$. They view professors as authorities with the "right" answer. "Teaching" entails explaining to them and they repeat it back on a test. This thinking was reflected in students' essays in comments like, "the teach [sic] are very informative and they tell you what you need to know and try to explain it in a way that I will remember....." Students expect to receive important information and become anxious if the information is not complete or is ambiguous. Comments such as "Chem teacher rambles on multiple topics some of which have no relevance to what we are learning so I'm left to gather information from the book" reflect this. When a student does not understand the topic or material covered, it is thought to be the professor's fault. Several student comments were similar to this one, "“...for lack of understanding due to the professor's teaching style." or "My hope is that next semester a new teacher might be able to grasp my interests more..."

One counter to dualism development found in the present analysis is the positive attitude students had toward study groups and group projects. Where a dualism developmental state would suggest students would be uncomfortable learning from their peers (only the professor knows the right answer - how could a peer know) the students in this study readily adapted to study groups and responded positively that they liked the fact that they could "...just run down the hall and get help or an answer to a question." It is important to note student development for a couple of reasons: first, moving students through developmental stages, particularly dualistic and multiplicity stages are often met with resistance and blame on others - the teacher, TAs, school, etc. and second, understanding students' developmental stages helps put some of their comments into perspective. It is also important to note that students often will not necessarily appreciate their movement to higher developmental levels until after the fact. At the time, students may feel they are being asked to do things with which they are not comfortable or familiar. Students are likely more comfortable with multiple-choice questions, passive learning, and believing that there is a "right" answer. Consequently, when these beliefs are tested or they are asked to actively participate in their learning, it feels uncomfortable and students complain, but after reflecting, students can often see that learning did occur despite their original beliefs.

The chemistry class presented an interesting opportunity to analyze because it was taught "differently," and almost all the students commented on the chemistry class. The chemistry class was a designed specifically for the Teniwe program by a veteran professor with a more deductive perspective and contextualizing the lessons with real world examples and research. Students recognized it was different from high school, and that the techniques they used in high school were not working in the chemistry class. Several students discovered that they were learning concepts rather than memorizing. Four students were frustrated and stated that they just couldn't memorize the information from the chemistry class and thought the professor "rambled." About 20 students said that the quizzes, text, and tests were disconnected. A couple of students realized they had to adapt their learning and read the text prior to the lectures and started enjoying the class. About three-fourths of the students reported liking the instructor and TAs from the class and often asked them for help and attended the review sessions. 


\section{Psychological processes}

Many of the essays provided insight to the student's psychological processes and attitudes. Bean ${ }^{12}$ suggested three psychological processes influenced a student's decision to continue in college: (1) self-efficacy; (2) approach/avoidance behavior theory; and (3) locus of control. Evidence of these processes were identified in the students' essays. Self-efficacy is the belief that the student can perform in a way to achieve grades that lead to increased self confidence and likelihood of persistence in college. This sentiment was echoed in a majority of the essays through statements such as, "If I just work hard enough I can get a good grade" although there did appear to be a decline toward the end of the semester in their self-efficacy with statements, "but I believe with good study habits that I don't have currently but might obtain... and "...I learned that I'm not always going to get the A in class, but as long as I tried my best that's all I can expect. At least I know I earned my grade."

Approach and avoidance are ways of coping in the environment to reduce the stress that environment creates. Positive adaptations lead to increased likelihood of persistence. Few students mentioned this aspect and those that did usually indicated they either went to the recreation center and worked out or relaxed with friends to relieve stress.

A majority of the students appeared to have a more internal locus of control. Students with an internal locus of control believe, for example, that their good grades are a result of effective studying. There were numerous comments suggesting "hard work" would result in good grades, "...I do think that with more effort I could have done much better..... "Students with an external locus of control believe they "got lucky" with their grade or that there is an ability that they do not control. About $10 \%$ of the students indicated an external locus of control suggesting they did not do well or they did do well because of "natural" inclinations saying, "I know that I am a smart person but there are just some areas that I fall short in. mostly [sic], these areas are what would come naturally to other people..."

\section{Differences between biotech and engineering LLC students}

Interestingly, the biotech LLC students appeared to be more satisfied with the entire LLC program than the engineering students. Where both groups were more satisfied at mid-term, the engineering students became increasingly dissatisfied as the semester progressed. Engineering students expressed satisfaction with the common class and residential arrangements but were almost offended by the freshmen seminar class and felt they had been "duped" and forced into taking a class that was "beneath" them. This general dislike toward the freshmen seminar class appeared to influence their outlook on the program and appeared to affect only the engineering LLC group and not the biotech students. This difference in attitude toward the freshmen seminar class may underscore the strong influence of peers in learning communities.

The engineering students believed that the freshmen seminar class put them "behind" in their programs, that the study skills were remedial, and that the activities were "busy work." In several engineering essays there was an indication of the effect of peer pressure "although many people seemed to not get much out of freshmen seminar, I thought it was a lot of fun. I was never 
at any point in the semester not eager to go to seminar because I knew it was a class that was more laid back than all the rest." This may provide a basis for recognizing a pattern to their behavior noting that academics are tightly intertwined around social networks.

\section{$\underline{\text { Student program evaluation }}$}

In general, students had positive comments and experiences with the common classes and common residence. Students believed they had ready-made study groups and peers they readily took advantage of. The freshmen seminar class appeared to be the source of most of the students' dissatisfaction with the program. Students believed they understood the objective of the freshmen seminar class to help them academically with their linked class content but felt that it was not implemented well. When the class consisted of activities to improve their study skills in a generic format - not specific to their linked classes - the students rebelled and perceived it as a remedial class, one that was beneath them.

Students believed the class was a type of "study hall" where they would receive help similar to that of tutoring and were disappointed when they did not have time to work on homework in class due to other class activities. Not a surprising reaction when many students indicated that in high school they did most of their homework at school. The majority of the students liked the freshmen seminar research activity and commented that it gave them some ideas of what they could study and how research worked at the university. A minority of students liked the freshmen seminar study skills activities and used them. The majority of students liked learning about campus resources and some indicated they had already used them.

\section{$\underline{\text { Limitations }}$}

It is important to note that students did not usually identify what they believed to be the cause of these benefits. Few attributed gains directly to the LLC program itself, but several attributed them to the freshmen seminar or their college experience. A few students felt that the freshmen seminar had only helped them with social skills, not academic skills, and that the increased socializing had actually detracted from the time they devoted to academic work. It is also important to note that some of the self-regulation issues that students chose to improve may have been suggested by the freshmen seminar facilitators as common obstacles to student success, such as improving study skills, time management, and adjusting expectations, since they were mentioned so often with the same terms.

Although these gains may be attributed to the Teniwe program, it is impossible to say this for certain, since some gains may be the expected result of time, maturation, and increasing familiarity with college requirements. Comparing these results with studies conducted on students at the same institution who aren't involved in such programs would provide a clearer picture of how the LLC program affected students' achievements.

\section{Conclusion}

The reflective essays provided insight about the LLC and the college experience from the students' perspective. Although the essays were written for an assignment in the freshmen 
seminar class, a lot of information about the LLC program, linked classes, and the social and academic development was mined from the essays.

Students wrote two essays, one mid-term in the semester and one at the end of the semester. The essays revealed students perceived college academics to be similar to high school academics and they employed the same study skills. Mid-term predictions for academic success were rosy but became less optimistic by the end of the semester. Many students recognized behaviors that were not conducive to academic success but did not appear motivated or did not know how to make changes.

Based on what students wrote, it appeared many were in the dualistic developmental stage as described by Perry ${ }^{5}$ where:

"The student sees the world in polar terms of we-right-good vs. otherwrong-bad. Right Answers for everything exist in the Absolute, known to Authority whose role is to mediate (teach) them. Knowledge and goodness are perceived as quantitative accretions of discrete rightness to be collected by hard work and obedience."

Overwhelmingly students suggested that effort was directly proportional to grades. A few suggested that academic success was something innate and comes naturally. Several students mentioned the belief that improved grades were directly related to increased effort in the class. Although the meaning of effort was not specified, it is interesting that some students might think that increasing their time "studying" will increase their grades rather than learning new study skills or changing strategies.

Students often blamed their lack of success on other factors such as extra work in other classes and unfair grading. Because most students are in a dualistic developmental stage, many of the traditional methods of college life, independence, developing self-regulation, accurately assessing what is known and not known, and utilizing peers are difficult to master. When the methods are not mastered, they are perceived as personal rebukes on a student's own person rather than an assessment of their learned knowledge.

Implications for future programs point to the way students learn techniques for academic improvement. This is an important issue considering the overall low scores from the Learning and Study Strategies Inventory (LASSI) surveys indicating students were not using effective study and learning techniques. Interestingly the prime complaint with the freshmen seminar class was that students perceived the attempts to teach and practice learning and study skills were that it was "busy work." Students also appeared to perceive homework as busy work too (from focus group results); consequently, how students are taught new study skills, how they integrate them into their coursework, and if instructors place emphasis on these skills can affect how the students interpret and use the information. Overtly connecting study skills activities to student learning aligned with course assignments could improve the academic achievement aspect of similar programs. 
Student reflective essays mirrored responses to focus group questions, course evaluations, and NSSE survey results in that they were meeting and making new friends, they were studying in groups, they often asked questions of each other, and thought the common living arrangements coupled with common classes were beneficial to them socially and academically.

Outcomes for the LLC were increased academic achievement, increased retention, and increased engagement in college. A variety of assessment measures was used to evaluate these outcomes including grades, retention to the next semester and next year, retention in the major, and engagement. Assessments were both quantitative and qualitative in an attempt to holistically evaluate the program and ascertain what components worked and which need improvement. The most revealing of these assessments was the reflective essay analysis and how it helped explain student outcomes.

\section{Academic achievement}

Students perceived the program as advantageous to their academic achievement via quick and accessible peer support as well as through ready-made study groups. Many students recognized the advantage of study groups, both academically and motivationally.

It was expected that students who participated in this LLC (living-learning community) would perform better in their common classes (as evidenced by higher grades in the common classes) because of additional social learning, the increased time-on-task due to the regular seminar meetings, ready-made study group partners, and close residential proximity to other students taking the same classes. Indeed, LLC students had higher average grades in analyzed classes although significantly higher in only one class, chemistry. Reflective essays, focus groups, and NSSE surveys results confirmed students were participating in these activities.

Another factor possibly affecting students' grades was student preparedness. To reduce this internal threat to validity, AIN (academic index number, a formula consisting of a student's high school GPA and SAT scores) was measured and tested for differences with control peers. Interestingly living-learning community participants had lower average AIN scores than control peers in all the analyzed classes. Contrary to what was expected, living-learning community students scored below national norms (on the whole) in learning strategies as measured by the Learning and Study Strategies Inventory (LASSI) surveys. Students wrote in their reflective essays that they were studying both alone and in groups but were still frustrated with their grades because they believed they were spending adequate time studying. When their grades were not what they wanted, they believed that more study time would have solved the problem rather than reexamining how they studied. Although the seminar class had a study and learning skills component, the students perceived it as remedial and said they already learned study and learning skills in high school. This feedback from the students suggests that how the study skills are taught needs to change. Results form the LASSI surveys and the students' frustration with their grades and study habits suggest that college-level study and learning skills still need to be taught and more importantly, practiced in an authentic setting. 


\section{Retention}

Students appeared to be building community by referring to fellow LLC students as "friends," even admitting to feeling peer pressure to study. Community building has been shown to increase retention; therefore, it was expected these students would be retained in significantly higher numbers than their control counterparts. This was not the case; LLC students were retained in college in equal numbers compared to control peers.

However, LLC engineering remained in engineering majors significantly more than control peers. This was not seen in the biotech LLC students, who where retained in comparable numbers as their peers. Self-selection into the program did not appear to bias retention because no difference was found in retention of LLC biotech science majors (although this is a small sample size of 22 students) compared to peers but was found in LLC majors compared to peers suggesting incoming motivation (self-selecting into the program) may not have affected retention.

\section{Engagement}

Many LLC students believed that without the program they would have studied alone more and not made as much effort to meet other students or participate in campus activities. Over half of the students mentioned that they had used university resources and had or were considering joining clubs. Almost all LLC students indicated that their social lives were full and that they met more people through the program. It was expected that LLC students would be more engaged due to time spent studying in groups, discussing ideas with others outside class, and participation in co-curricular activities. Triangulation with reflective essays, focus groups, and course evaluations, and observations repeatedly confirmed this expectation.

Students completing the NSSE engagement surveys reported they were more engaged overall in college than were previous LLC classes, other freshmen engineering peers at the same institution, freshmen engineering students at peer institutions and freshmen engineering students at all NSSE surveyed institutions. The interesting exception to this was the LLC students' responses to their overall educational experience and satisfaction with the college questions. Teniwe students indicated they were not as satisfied with either having a -.61 and -.67, respectively (a negative medium effect size) when compared with previous LLC students' responses. Future studies that examining this phenomenon would help elucidate this apparent contradiction.

Students' goals and first-year experiences have not changed dramatically in the past 20 years. Erickson \& Strommer ${ }^{13}$ echoed similar observations about freshmen in the 1980's and 1990 's as was found in this study. Freshmen goals for college were making friends, getting good grades, and becoming independent.

Most students in this study were primarily in the dualistic developmental stage. This study found freshmen characteristics consistent with dualistic definitions. ${ }^{5}$ An interesting observation and apparent contradiction to the dualistic development stage was how readily accepted group work and group projects were and how quick students were to ask one another 
for help. It appears that developing community through a LLC does provide an advantage to the students academically and developmentally by aiding those developmental transitions.

The results of this study suggest that increasing retention in specific majors, engagement in college activities, and academic achievement increase with positive social and academic experiences. Understanding the LLC and college experience from the students' perspective can provide a more effective means for identifying aspects of a program that are beneficial as well as those that are not. The reflective analysis performed in this study indicated that students were in a dualistic developmental stage. Factors that were important to these students such as good grades, perceived fairness, fitting in with peers, and receiving constructive feedback are not always found in freshmen-level classes. Consequently, when institutions meet these needs and transition students through a holistic experience encompassing both social and academic worlds with a LLC, a potentially negative experience can be transformed into a positive and fondly remembered time.

\section{References}

${ }^{1}$ Erwin, T. D. (1991) Assessing Student Learning and Development : A Guide to Principles, Goals, and Methods of Determining College Outcomes. San Fancisco:Jossey-Bass.

${ }^{2}$ Moore, W. S. (1995) "My Mind Exploded: Intellectual Development as a Critical Framework for Understanding and Assessing Collaborative Learning." In Assessment in and of Collaborative Learning: A Handbook of Strategies, edited by Washington Center Evaluation Committee. Olympia, WA: Washington Center for Improving the Quality of Undergraduate Education, 1995.

${ }^{3}$ Tinto, V., Love, A. G., \& Russo, P. (1995) “Assessment of Collaborative Learning Programs: The Promise of Collaborative Research." In Assessment in and of Collaborative Learning: A Handbook of Strategies, edited by Washington Center Evaluation Committee. Olympia, WA: Washington Center for Improving the Quality of Undergraduate Education, 1995.

${ }^{4}$ Wilkie, G. (1995). Assessing Learning Community Effectiveness: An Institutional View In Assessment in and of Collaborative Learning: A Handbook of Strategies, edited by Washington Center Evaluation Committee. Olympia, WA: Washington Center for Improving the Quality of Undergraduate Education, 1995.

${ }^{5}$ Perry, W. G., Jr. (1970). Forms of Intellectual and Ethical Development in the College Years: A Scheme. New York: Holt.

${ }^{6}$ Light, J. (2005). Developing and assessing a holistic living-learning community for engineering and science freshmen. Unpublished doctoral dissertation, Washington State University, Washington.

${ }^{7}$ Kuh, G.D. (2001). The National Survey of Student Engagement: Conceptual framework and overview of psychometric properties. Bloomington, IN: Indiana University Center for Postsecondary Research. Accessed 9/26/03 from http://nsse.iub.edu/html/psychometric_framework_2002.htm.

${ }^{8}$ Cohen, J. (1988) Statistical Power Analysis for the behavioral Sciences, $2^{\text {nd }}$ ed. Lawrence Erlbaum Associates, Inc. Hillsdale, New Jersey.

${ }^{9}$ Green, S. B., \& Salkind, N. J., (2003). Using SPSS for windows and macintosh: Analyzing and understanding data. $3^{r d} E d$. Prentice Hall: Upper Saddle River, NJ. 
${ }^{10}$ Weinstein, C. E., Schulte, A. C. \& Palmer, D. R., (1996). Learning and Study Strategies Inventory (LASSI) $2^{\text {nd }}$ Ed. H \& H Publishing Inc., Clearwater, FL. Accessed 2/12/04 from

http://www.hhpublishing.com/_assessments/LASSI/index.html

${ }^{11}$ Strauss, A. \& Corbin, J., (1990). Basics of qualitative research: Grounded theory procedures and techniques. Sage Publications, Inc.: Newbury Park, CA

${ }^{12}$ Bean, J. P., (2005). Nine themes of college student retention. In College student retention, ed. A. Seidman, 215243. Westport, CT:Praeger Publishers

${ }^{13}$ Erickson B. L., \& Strommer, D. W., 1991. Teaching college freshmen. Jossey-Bass, San Francisco: CA 